\title{
Article \\ Quality Evaluation of Lemon Cordial Stored at Different Times with Microwave Heating (Pasteurization)
}

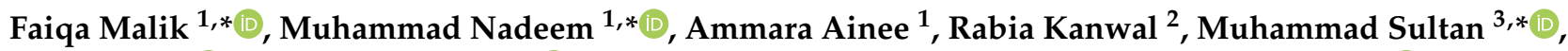 \\ Aqsa Iqbal ${ }^{1}\left(\mathbb{D}\right.$, Samy F. Mahmoud ${ }^{4}\left(\mathbb{D}\right.$, Garsa Ali Alshehry ${ }^{5}$, Huda Abdalrahman Al-Jumayi ${ }^{5}$ \\ and Eman Hassan Ahmed Algarni ${ }^{5}$
}

\section{check for}

updates

Citation: Malik, F.; Nadeem, M.; Ainee, A.; Kanwal, R.; Sultan, M.; Iqbal, A.; Mahmoud, S.F.; Alshehry, G.A.; Al-Jumayi, H.A.; Algarni, E.H.A. Quality Evaluation of Lemon Cordial Stored at Different Times with Microwave Heating

(Pasteurization). Sustainability 2022, 14, 1953. https://

doi.org/10.3390/su14041953

Academic Editor: Rajeev Bhat

Received: 10 January 2022

Accepted: 3 February 2022

Published: 9 February 2022

Publisher's Note: MDPI stays neutral with regard to jurisdictional claims in published maps and institutional affiliations.

Copyright: (C) 2022 by the authors. Licensee MDPI, Basel, Switzerland. This article is an open access article distributed under the terms and conditions of the Creative Commons Attribution (CC BY) license (https:// creativecommons.org/licenses/by/ $4.0 /)$.
1 Institute of Food Science and Nutrition, University of Sargodha, Sargodha 40100, Pakistan; ammara.ainee@uos.edu.pk (A.A.); aqsa0057@gmail.com (A.I.)

2 Post-Harvest Research Centre, Ayub Agriculture Research Institute, Jhang Road, Faisalabad 38850, Pakistan; rabiak_018@yahoo.com

3 Department of Agricultural Engineering, Bahauddin Zakariya University, Bosan Road, Multan 60800, Pakistan

4 Department of Biotechnology, College of Science, Taif University, P.O. Box 11099, Taif 21944, Saudi Arabia; s.farouk@tu.edu.sa

5 Department of Food Science and Nutrition, College of Science, Taif University, Taif 21944, Saudi Arabia; garsa.a@tu.edu.sa (G.A.A.); huda.a@tu.edu.sa (H.A.A.-J.); eman1400@tu.edu.sa (E.H.A.A.)

* Correspondence: faiqamalikft@gmail.com (F.M.); nadeem.abdul@uos.edu.pk (M.N.); muhammadsultan@bzu.edu.pk (M.S.); Tel.: +92-300-604-9890 (M.N.)

\begin{abstract}
Consumer interest in food quality and safety has shifted over time, as consumers increasingly prefer minimally processed items. As a result, numerous non-thermal approaches have been implemented due to their potential to preserve the nutritional profile of products along with lengthening their storability. Microwaving, a green processing technique, volumetrically heats the product because of the interactions developed between charged ions, polar water molecules of foodstuff and the incoming electromagnetic waves. The study was mapped out to investigate the effect of microwave exposure time $(60,90$ and $120 \mathrm{~s})$ at fixed power $(1000 \mathrm{~W})$ and frequency $(2450 \mathrm{MHz})$ on physicochemical properties, phytochemical constituents, antioxidant potential and microbial counts of lemon cordial stored at refrigerated temperature $\left(4 \pm 2{ }^{\circ} \mathrm{C}\right)$. The mentioned parameters were analyzed after an interval of 30-90 days. Statistical findings illustrated a highly significant $(p \leq 0.01)$ impact of microwave treatment and storage on titratable acidity, $\mathrm{pH}$, total soluble solids, total phenolic contents, total flavonoids contents, antioxidant potential and total plate count. Sample microwaved for $120 \mathrm{~s}$ showed the highest $\mathrm{pH}$ values $(2.45 \pm 0.050)$, total soluble solids $\left(56.68 \pm 2.612{ }^{\circ} \mathrm{B}\right)$ and antioxidant activity (1212.03 $\pm 716.5 \mu \mathrm{g}$-equivalent of ascorbic acid per $100 \mathrm{~mL}$ of cordial); meanwhile, it exhibited the lowest total plate counts $(1.75 \pm 0.144 \log 10 \mathrm{CFU} / \mathrm{mL})$. Therefore, microwaving can be suggested as a suitable alternate to traditional pasteurization techniques as well as to chemical preservatives.
\end{abstract}

Keywords: lemon cordial; microwave; preservation; green processing; antioxidant potential

\section{Introduction}

Prevention of various diseases is possible by including fruits in our diet as they are an excellent source of minerals, vitamins, antioxidant components and other phytoconstituents [1]. Generation of free radicals, which are triggering factors for several acute and chronic diseases, can be prohibited by the antioxidant potential of the fruits, thus promoting a healthier life [2]. Elevated levels of plasma carotenoids and vitamin $\mathrm{C}$ are associated with the increased intake of fruits, which ultimately reduces the probability of diabetes, cardiovascular diseases, neurological disorders and cancer [3,4].

Citrus limon (L.) Burm. f., most commonly known as lemon, a yellow-colored edible fruit, is the third most widely produced representative of the Rutaceae family and hybrid 
of genus Citrus-just after orange and mandarin-worldwide [5]. Citrus limon can either be consumed as a fresh fruit, as beverage, as cooking material or for preservation purposes. Because of its tart flavor, it is most often used in manufacturing of beverages, desserts, ice creams, salad dressings, jams, jellies, pickles and in several kinds of vegetable and meat dishes [6,7].

Citrus limon is also a good supplier of a variety of phytoconstituents, including phenolics. Among these phenolics, eriocitrin, coumarins, flavonoids and limonoid glycosides are present in adequate concentrations [8]. Consumption of Citrus limon has shown reduction in the risk of several types of cancers, along with cardiovascular disorders [7]. Organic compounds present in lemons are effective against asthma and can serve as antidepressants and stress relievers. Moreover, these also stimulate digestion and are effective in case of $\mathrm{flu}$, fever, boils and in several kinds of ulcers, particularly mouth ulcers [9]. In the past, when vitamin $C$ was not discovered, the juice extracted from Citrus limon fruit was used for treatment of scurvy [10]. Additionally, the juice has also served as traditional medicine for the cure of hypertension, common cold, sore throat, chest pain and rheumatism [11].

Cordial can be defined as sparkling, clear, or syrup concentrated fruit juice formed by the complete removal of pulp and other suspended particles, and needs to be diluted upon consumption [12] (Yusof and Chiong). Citrus limon is also cultivated in Pakistan and it occupies 6th position in terms of area and production [13]. Due to more production and less utilization, the fruit obtain wasted. In order to overcome the losses, there is a need to convert them to some value-added products, such as squashes and cordials. The study focused on making cordial from lemons in order to meet the rising consumer demands regarding new value-added products.

During the last couple of years, consumers' interest throughout the entire world has been changed regarding quality and safety of the food product [14]. They demand minimally processed products that are not only healthy, but are also processed by means of safe preservation techniques, so that their quality and nutritional profile are not affected [15].

In general, fruit juices are preserved by heating them near the boiling point of water, or slightly below it, for a set amount of time, to kill or inactivate deterioration-causing microbes and enzymes. [16]. Although traditional heating methods ensure the safety and stability of the juices, they greatly affect the phytochemical profiles of the fruit juices, along with causing a decline in the physical and chemical properties, the nutritional profiling and the volatile compounds [14,17]. Similarly, chemical preservatives are other means to extend the shelf life of products, but these chemicals also produce several health complications in humans, particularly cancer, neurological dysfunction, asthma, hyperactivity and hypersensitivity, dermatitis, allergies and gastrointestinal and respiratory disorders [18-20].

Due to disadvantages of thermal techniques and chemical preservatives, several novel non-thermal techniques have been in practice to enhance the shelf stability of processed products [21,22]. Microwaving, a novel technique, utilizes electromagnetic waves that heat the product by means of molecular interaction, as generated by the electromagnetic field. In this technique, there is a direct interaction of food particles with that of the incoming waves. As a result of this direct contact, penetration of heat is easier within the food, and thus volumetric heating takes place [23,24]. Microwaving also preserves the nutritional contents of products to a greater extent, such as the retention of vitamins, thus enhancing the quality and safety of products through the inactivation of microbes and enzymes within a short duration $[25,26]$.

Keeping the above benefits in mind, the present research aimed to develop lemon cordial and to investigate the effect of the microwave technique for preserving lemon cordial's physicochemical properties and microbial counts, and to determine the effect of microwave treatment on the shelf stability of lemon cordial at refrigerated temperature for a period of 90 days. 


\section{Materials and Methods}

\subsection{Collection of Fruit}

Lemons were purchased from a local farm and sorted to separate damaged and diseased fruits from healthy fruit. Subsequently, the fruits were washed using tap water to remove dirt and dust.

\subsection{Chemicals and Reagents}

All the chemicals used in analysis were of analytical grade and purchased from SigmaAldrich (Gillingham, UK), available in the local market.

\subsection{Preparation of Lemon Cordial}

Extraction of the juice from the fresh fruit was carried out using a manual juice extractor. After extraction, the juice was filtered through 4 folds of muslin cloth to remove seeds and juice vesicles to obtain clear filtrate. The remaining ingredients, such as sugar, water, citric acid and lemon-yellow color, were added to the cleared juice (Table 1) with constant stirring to obtain lemon cordial ( $45^{\circ}$ brix), following the procedure of [27], with some modifications.

Table 1. Formulation of lemon cordial.

\begin{tabular}{cc}
\hline Ingredients & Quantity \\
\hline Clarified lemon juice & $1 \mathrm{~L}$ \\
Sugar & $1.5 \mathrm{Kg}$ \\
Water & $500 \mathrm{ml}$ \\
Citric acid & $1 \mathrm{~g} / 1 \mathrm{~L}$ \\
Carboxymethyl cellulose & $1 \mathrm{~g} / 1 \mathrm{~L}$ \\
Lemon-yellow coloring & $0.1 \mathrm{~g} / 1 \mathrm{~L}$ \\
\hline
\end{tabular}

\subsection{Microwave Processing of Lemon Cordial}

The cordial was subjected to microwave treatment with a domestic microwave processor (Model No: DW- 131A operating at $1000 \mathrm{~W}$ power and frequency of $2450 \mathrm{MHz}$ ) for 60,90 and $120 \mathrm{~s}$. Microwaving of cordial samples $(200 \mathrm{~mL})$ was carried out in sterilized beakers $(500 \mathrm{~mL})$. Immediately after pasteurization, the product was transferred and packed in presterilized $250 \mathrm{~mL}$ plastic bottles that were immersed in ice cold water to prevent shrinkage of the bottles and to cool the product instantly, as the temperature after pasteurization for $120 \mathrm{~s}$ reaches $90 \pm 2{ }^{\circ} \mathrm{C}$. The treated lemon cordial was later stored at refrigerated temperature $\left(4 \pm 2{ }^{\circ} \mathrm{C}\right)$ for further study (Figure 1$)$.

\subsection{Chemical Preservative}

In treatment, $\mathrm{T}_{0+}$ potassium metabisulphite (KMS) was used as preservative to compare the cordial with other treatments, as well as with the control $\left(\mathrm{T}_{0-}\right)$, without adding chemical preservatives and microwave application. The treatment plan is depicted in (Table 2).

Table 2. Treatment plan of lemon cordial.

\begin{tabular}{ccl}
\hline Treatments & $\begin{array}{c}\text { Microwave Time } \\
\text { (Seconds)/Preservatives }\end{array}$ & Storage Conditions \\
\hline $\mathrm{T}_{0+}$ & $0.1 \%(\mathrm{KMS})$ & Temperature $\left(4 \pm 2{ }^{\circ} \mathrm{C}\right)$ \\
$\mathrm{T}_{0-}$ & - & Temperature $\left(4 \pm 2{ }^{\circ} \mathrm{C}\right)$ \\
$\mathrm{T}_{1}$ & $60 \mathrm{~s}$ & Temperature $\left(4 \pm 2{ }^{\circ} \mathrm{C}\right)$ \\
$\mathrm{T}_{2}$ & $90 \mathrm{~s}$ & Temperature $\left(4 \pm 2{ }^{\circ} \mathrm{C}\right)$ \\
$\mathrm{T}_{3}$ & $120 \mathrm{~s}$ & Temperature $\left(4 \pm 2{ }^{\circ} \mathrm{C}\right)$ \\
\hline
\end{tabular}



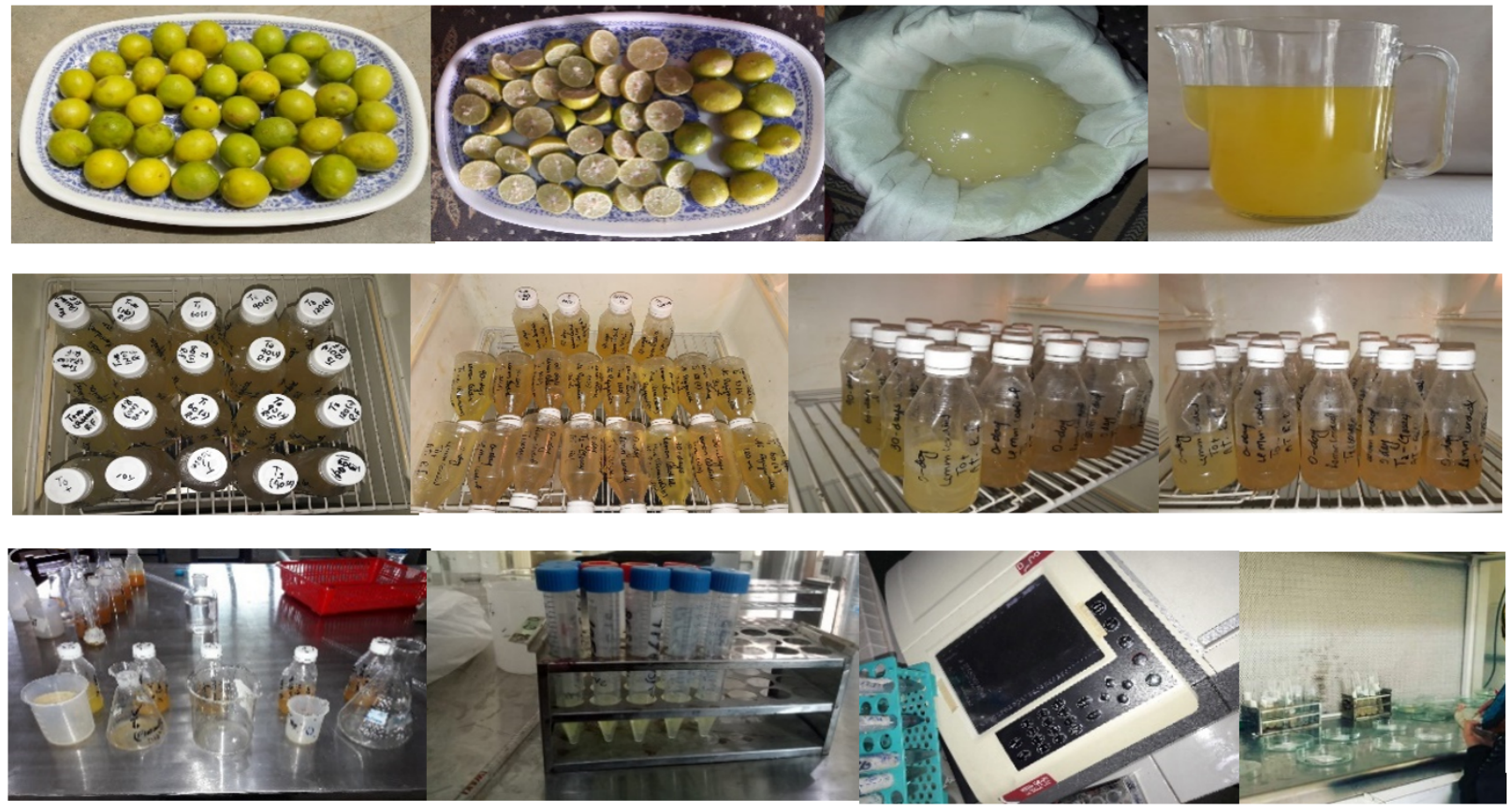

Figure 1. Processing of lemon cordial (1st row); preservation of lemon cordial at refrigerated temperature $\left(4 \pm 2{ }^{\circ} \mathrm{C}\right)$ (2nd row); different analysis of lemon cordial (3rd row).

\subsection{Physicochemical Analysis}

Acidity was accessed through procedure no. 942.15, as mentioned in [28]. $\mathrm{pH}$ was evaluated by using a digital $\mathrm{pH}$ meter (AD 1040 Benchtop meter, Adwa, Hungary), as per method no. 981.12 of [28]. Degree brix were measured using a hand refractometer (Atago, Japan), according to method no 932.12, as explained by [28].

\subsection{Determination of Total Phenolic Contents}

Total phenolics of lemon cordial were accessed through a modified Folin-Ciocalteu reagent method, as explained by [29]. A diluted lemon cordial sample $(0.5 \mathrm{~mL}$, or $500 \mu \mathrm{L})$ was used for analysis and absorbance was measured by spectrophotometer at $760 \mathrm{~nm}$. Gallic acid (in ethanol) was taken as standard, and the findings of total phenolic contents were indicated as $\mathrm{mg}$ of gallic acid equivalents (GAE) per $100 \mathrm{~mL}$ of lemon cordial.

\subsection{Determination of Total Flavonoids Contents}

The total flavonoids of the lemon cordial were accessed by using aluminum chloride reagent through procedure described by [30]. Diluted lemon cordial samples $(0.25 \mathrm{~mL}$ or $250 \mu \mathrm{L}$ ) were used for analysis and absorbance was measured by spectrophotometer at $510 \mathrm{~nm}$ wavelength. Catechin (in ethanol) was taken as standard, and the findings of total flavonoids were demonstrated as $\mathrm{mg}$ of $(+)$ —catechin equivalent (CE) per $100 \mathrm{~mL}$ of lemon cordial.

\subsection{Determination of Total Antioxidant Activity}

Total antioxidant activity of all the diluted lemon cordial samples was accessed through the procedure described by [31]. Diluted lemon cordial samples $(0.4 \mathrm{~mL}$ or $400 \mu \mathrm{L})$ were used for analysis and absorbance was probed through a spectrophotometer at $695 \mathrm{~nm}$ wavelength. Standard calibration curves were made by using ascorbic acid. Findings of total antioxidant activity were demonstrated as $\mu \mathrm{g}$ ascorbic acid equivalent (AAE) per $\mathrm{mL}$ sample. 


\subsection{Microbiological Analysis}

Total plate count of all lemon cordial samples was accessed through the [32] standard method of the Bacteriological Analytical Manual [33]. A measure of $1 \mathrm{~mL}$ of lemon cordial sample was poured in presterilized test tubes with the aid of sterilized pipette. To these test tubes, $9 \mathrm{~mL}$ of normal saline solution was added to make dilutions. Serial dilutions were made by transferring $1 \mathrm{~mL}$ of previously generated dilution to a test tube, containing $9 \mathrm{~mL}$ of normal saline as diluent. The prepared dilutions were shaken well to prevent the settling of suspended materials. Subsequently, the prepared dilutions were sprinkled upon the control plates for each series of samples. After the media and poured dilutions had completely solidified, the Petri dishes were inverted and placed in an incubator at $35{ }^{\circ} \mathrm{C}$ for $48 \mathrm{~h}$. Plates with colonies between 30 and 300 were compounded with dilution factor based on the number of colonies that appeared on the plates. The arithmetic average was calculated as the total plate count per $\mathrm{mL}$.

\subsection{Statistical Analysis}

Findings of each parameter were statistically analyzed through statistics software. ANOVA technique and Tukey's HSD test were employed to determine difference among means by having the level of significance at $5 \%$ confidence interval, according to the method illustrated by [34].

\section{Results and Discussion}

The impact of microwave treatments and storage on titratable acidity of lemon cordial retained at refrigerated temperature is illustrated in (Table 3). Microwaving produced a highly significant impact $(p<0.01)$ on titratable acidity, leading to a gradual reduction in the acidity of lemon cordial. The highest value for acidity was exhibited by $\mathrm{T}_{0-}$, proclaiming a mean value of $0.38 \pm 0.038 \%$, while the lowest was observed in $\mathrm{T}_{3}$, exhibiting a mean value of $0.32 \pm 0.045 \%$. The observations are in conformance with those obtained by Pandiselvam et al. [35] and Bozkir et al. [36], who reported the same decreasing tendency in the acidity after the application of microwave treatment on kalparasa and apple juice. They articulated that increased time and temperature during microwave treatment resulted in destruction of fermenting microbes, due to which the production of organic acids declines. Considering the impact of storage on the titratable acidity, it was noticed that titratable acidity increased gradually throughout the storage duration. The highest mean value of $0.41 \pm 0.014 \%$ was observed at 90 days, while the lowest mean value of $0.29 \pm 0.024 \%$ was examined at 0 days. These results are supported by the findings of Pandiselvam et al. [35], who reported an increase in titratable acidity of microwave-treated kalparasa (coconut inflorescence sap) upon refrigeration storage and claimed that an increased production of organic acids during anaerobic fermentation is responsible for an increase in acidity. Similarly, Palanisamy et al. [37] reported that increase in the acidity of noni fruit juice blended squash during storage was caused by the soluble proteins hydrolyzing to free amino acids, which ultimately resulted in an interlinkage of citric acid in squash. An increase in acidity during storage in mixed fruit squash and microwaved apple puree was also communicated by Jothi et al. [38] and Picouet et al. [39], respectively.

Microwave treatment and storage duration both produced a highly significant impact $(p \leq 0.01$ ) upon the $\mathrm{pH}$ of the lemon cordial (Table 4). Gradual increase in the $\mathrm{pH}$ of the lemon cordial upon microwaving was observed. The highest $\mathrm{pH}$ value was expressed by $\mathrm{T}_{3}$, with a mean value of $2.45 \pm 0.050$, while the lowest was observed in $\mathrm{T}_{0-}$, exhibiting a mean value of $2.38 \pm 0.046$. A similar trend for $\mathrm{pH}$ was reported by Pandiselvam et al. [35] in microwave-treated kalparasa, who documented that reduction in the contents of organic acids of kalparasa, as result of heating, increased the $\mathrm{pH}$. Picouet et al. [39] articulated that the $\mathrm{pH}$ of apple puree, when subjected to microwaving for $35 \mathrm{~s}$ at $652 \mathrm{~W}$ power, slightly enhanced from 3.2 to 3.3. Considering the impact of storage on the $\mathrm{pH}$, it was noticed that it decreased throughout the storage duration. The highest mean value of $2.46 \pm 0.027$ was noticed at start of study while the lowest mean value of $2.35 \pm 0.024$ was observed 
at 90 days. The observation of the conducted study correlates with those proposed by Palanisamy et al. [37], Yadav et al. [40] and Jothi et al. [38]. They claimed that the pH of noni fruit juice blended squash, guava mango RTS and squash and mixed fruit squash made from banana, papaya and carrot juice decreased during storage, which was attributed to the accumulation of acidic compounds-particularly lactic acid and acetic acid—because of the activity of microbes during natural fermentation process.

Table 3. Titratable acidity (\%) of lemon cordial.

\begin{tabular}{|c|c|c|c|c|c|}
\hline \multirow{2}{*}{ Treatments } & \multicolumn{4}{|c|}{ Storage (Days) } & \multirow{2}{*}{ Means } \\
\hline & 0 & 30 & 60 & 90 & \\
\hline $\mathrm{T}_{0-}$ & $0.33^{\mathrm{e}-\mathrm{g}} \pm 0.007$ & $0.35^{\text {ef }} \pm 0.001$ & $0.39^{b c} \pm 0.004$ & $0.43^{a} \pm 0.003$ & $0.38^{\mathrm{A}} \pm 0.038$ \\
\hline $\mathrm{T}_{0+}$ & $0.30^{\mathrm{i}} \pm 0.013$ & $0.34^{\text {ef }} \pm 0.004$ & $0.37^{\mathrm{d}} \pm 0.010$ & $0.41^{\mathrm{a}} \pm 0.004$ & $0.36^{\mathrm{B}} \pm 0.044$ \\
\hline $\mathrm{T}_{1}$ & $0.29 \mathrm{ij} \pm 0.010$ & $0.34^{\mathrm{e}-\mathrm{g}} \pm 0.004$ & $0.35^{\mathrm{de}} \pm 0.006$ & $0.41^{\mathrm{ab}} \pm 0.006$ & $0.35^{\mathrm{C}} \pm 0.045$ \\
\hline $\mathrm{T}_{2}$ & $0.28^{\mathrm{j}} \pm 0.004$ & $0.32^{\text {gh }} \pm 0.006$ & $0.34^{\text {ef }} \pm 0.004$ & $0.39^{b c} \pm 0.004$ & $0.33^{\mathrm{D}} \pm 0.044$ \\
\hline $\mathrm{T}_{3}$ & $0.27^{\mathrm{j}} \pm 0.004$ & $0.30^{\mathrm{hi}} \pm 0.007$ & $0.33^{\mathrm{fg}} \pm 0.004$ & $0.39^{c} \pm 0.004$ & $0.32^{\mathrm{E}} \pm 0.045$ \\
\hline Means & $0.29^{\mathrm{D}} \pm 0.024$ & $0.33^{C} \pm 0.017$ & $0.36^{\mathrm{B}} \pm 0.024$ & $0.41^{\mathrm{A}} \pm 0.014$ & \\
\hline
\end{tabular}

Values exhibiting similar alphabets are statistically non-significant. $\mathrm{T}_{0-}-$ control (lemon cordial with no preservative or treatment); $\mathrm{T}_{0+}$ - control (lemon cordial preserved with $\mathrm{KMS}$ ); $\mathrm{T}_{1}$ - microwave treatment (60 s); $\mathrm{T}_{2}$ microwave treatment (90 s); $\mathrm{T}_{3}$-microwave treatment (120 s).

Table 4. $\mathrm{pH}$ of lemon cordial during storage.

\begin{tabular}{|c|c|c|c|c|c|}
\hline \multirow{2}{*}{ Treatments } & \multicolumn{4}{|c|}{ Storage (Days) } & \multirow{2}{*}{ Means } \\
\hline & 0 & 30 & 60 & 90 & \\
\hline $\mathrm{T}_{0-}$ & $2.43^{\mathrm{c}-\mathrm{e}} \pm 0.015$ & $2.40^{\mathrm{e}-\mathrm{g}} \pm 0.015$ & $2.36^{\mathrm{g}-\mathrm{i}} \pm 0.023$ & $2.32^{\mathrm{j}} \pm 0.010$ & $2.38^{\mathrm{D}} \pm 0.046$ \\
\hline $\mathrm{T}_{0+}$ & $2.45^{b-d} \pm 0.012$ & $2.42^{\mathrm{d}-\mathrm{f}} \pm 0.015$ & $2.38^{\mathrm{g}-\mathrm{i}} \pm 0.021$ & $2.34 \mathrm{ij} \pm 0.010$ & $2.40^{C} \pm 0.044$ \\
\hline $\mathrm{T}_{1}$ & $2.46^{\mathrm{bc}} \pm 0.012$ & $2.43^{\mathrm{c}-\mathrm{e}} \pm 0.010$ & $2.38^{\mathrm{f}-\mathrm{h}} \pm 0.015$ & $2.35^{\mathrm{h}-\mathrm{j}} \pm 0.010$ & $2.41^{\mathrm{BC}} \pm 0.044$ \\
\hline $\mathrm{T}_{2}$ & $2.46^{\mathrm{bc}} \pm 0.015$ & $2.44^{\mathrm{b}-\mathrm{d}} \pm 0.006$ & $2.40^{\mathrm{e}-\mathrm{g}} \pm 0.006$ & $2.37^{\mathrm{g}-\mathrm{i}} \pm 0.010$ & $2.42^{\mathrm{B}} \pm 0.040$ \\
\hline $\mathrm{T}_{3}$ & $2.50^{\mathrm{a}} \pm 0.006$ & $2.48^{\mathrm{ab}} \pm 0.006$ & $2.42^{\mathrm{d}-\mathrm{f}} \pm 0.006$ & $2.38^{\mathrm{f}-\mathrm{h}} \pm 0.006$ & $2.45^{\mathrm{A}} \pm 0.050$ \\
\hline Means & $2.46^{\mathrm{A}} \pm 0.027$ & $2.43^{B} \pm 0.029$ & $2.39^{C} \pm 0.023$ & $2.35^{\mathrm{D}} \pm 0.024$ & \\
\hline
\end{tabular}

Values exhibiting similar small alphabets are statistically non-significant $(p>0.05)$ whereas similar capital alphabets represent statistically non-significant $(p>0.05)$ difference among overall means values. $\mathrm{T}_{0-}$ - control (lemon cordial with no preservative and treatment); $\mathrm{T}_{0+}$ - control (lemon cordial preserved with KMS); $\mathrm{T}_{1}$ - microwave treatment (60 s); $\mathrm{T}_{2}$-microwave treatment (90 s); $\mathrm{T}_{3}$-microwave treatment (120 s).

The influences of microwave treatment and storage on the total soluble solids ( ${ }^{\circ}$ brix) of lemon cordial at refrigerated temperature are illustrated in (Table 5). The presented data clearly depicts that microwave as well as storage duration produced a highly significant impact $(p \leq 0.01)$ upon the ${ }^{\circ}$ brix of lemon cordial. A gradual increase in the ${ }^{\circ}$ brix of lemon cordial was observed upon microwaving. The highest ${ }^{\circ}$ brix were exhibited by $\mathrm{T}_{3}$ expressing a mean value of $56.68 \pm 2.612{ }^{\circ} \mathrm{B}$ while the lowest were observed in $\mathrm{T}_{0-}$, exhibiting a mean value of $50.83 \pm 0.755^{\circ} \mathrm{B}$. The observations of the study are supported by the findings of Sattar et al. [41], Song et al. [42] and Fazaeli et al. [43], who stated an increment in total soluble solids of functional peach beverage, apple and black mulberry juice upon microwaving. They figured out that during microwaving, evaporation of water from the product takes place, and this phenomenon is directly linked to the increase in the internal temperature of juice. It leads to juice concentration and increase in total soluble solid contents. Considering the impact of storage, it was noticed that ${ }^{\circ}$ brix of lemon cordial decreased throughout the storage duration. The highest mean value of $55.28 \pm 3.499^{\circ} \mathrm{B}$ was noticed at 0 days while the lowest mean value of $51.05 \pm 1.746^{\circ} \mathrm{B}$ was observed at 90 days. These findings are similar to those reported by Pandiselvam et al. [35] and Yusof and Chiong [12]. During storage sugars are utilized by the fermenting microbes, particularly yeast and acetic acid bacteria, as a source of nutrient, thus converting them into their respective acids and alcohol, along with the liberation of $\mathrm{CO}_{2}$. 
Table 5. ${ }^{\circ}$ Brix of lemon cordial during storage.

\begin{tabular}{|c|c|c|c|c|c|}
\hline \multirow{2}{*}{ Treatments } & \multicolumn{4}{|c|}{ Storage (Days) } & \multirow{2}{*}{ Means } \\
\hline & 0 & 30 & 60 & 90 & \\
\hline $\mathrm{T}_{0-}$ & $51.83^{g} \pm 0.208$ & $51.13^{h} \pm 0.058$ & $50.33^{\mathrm{i}} \pm 0.153$ & $50.00^{\mathrm{i}} \pm 0.100$ & $50.83^{\mathrm{E}} \pm 0.755$ \\
\hline $\mathrm{T}_{0+}$ & $51.73^{g} \pm 0.252$ & $51.13^{h} \pm 0.058$ & $50.97^{\mathrm{h}} \pm 0.058$ & $50.30^{\mathrm{i}} \pm 0.200$ & $51.03^{\mathrm{D}} \pm 0.552$ \\
\hline $\mathrm{T}_{1}$ & $55.17^{d} \pm 0.289$ & $51.97 \mathrm{~g} \pm 0.058$ & $50.07^{\mathrm{i}} \pm 0.058$ & $49.13^{j} \pm 0.058$ & $51.58^{\mathrm{C}} \pm 2.413$ \\
\hline $\mathrm{T}_{2}$ & $56.93^{b} \pm 0.115$ & $53.90^{\mathrm{e}} \pm 0.100$ & $53.17^{\mathrm{f}} \pm 0.058$ & $51.90^{\mathrm{g}} \pm 0.100$ & $53.98^{\mathrm{B}} \pm 1.936$ \\
\hline $\mathrm{T}_{3}$ & $60.73^{a} \pm 0.252$ & $56.10^{c} \pm 0.100$ & $56.00^{\mathrm{c}} \pm 0.100$ & $53.90^{\mathrm{e}} \pm 0.100$ & $56.68^{\mathrm{A}} \pm 2.612$ \\
\hline Means & $55.28^{\mathrm{A}} \pm 3.499$ & $52.85^{\mathrm{B}} \pm 1.983$ & $52.11^{C} \pm 2.311$ & $51.05^{\mathrm{D}} \pm 1.746$ & \\
\hline
\end{tabular}

Values exhibiting similar small alphabets are statistically non-significant $(p>0.05)$ whereas similar capital alphabets represent statistically non-significant $(p>0.05)$ difference among overall means values. $\mathrm{T}_{0-}$ - control (lemon cordial with no preservative and treatment); $\mathrm{T}_{0+}$ - control (lemon cordial preserved with KMS); $\mathrm{T}_{1}$ - microwave treatment $(60 \mathrm{~s}) ; \mathrm{T}_{2}$-microwave treatment $(90 \mathrm{~s}) ; \mathrm{T}_{3}$-microwave treatment (120 s).

Data demonstrating the influence of microwave treatment and storage on total phenolic contents of lemon cordial during storage at refrigeration temperature is depicted in (Table 6). Microwave treatment as well as storage duration produced a highly significant impact $(p \leq 0.01)$ upon total phenolic contents of lemon cordial. Reduction in total phenolic contents of lemon cordial was observed upon the application of microwave. The highest values of total phenolics were exhibited by $\mathrm{T}_{0+}$, expressing a mean value of $399.08 \pm 67.745 \mathrm{mg}$ GAE per $100 \mathrm{~mL}$ of cordial, while the lowest were observed in $\mathrm{T}_{3}$, exhibiting a mean value of $346.42 \pm 64.387 \mathrm{mg}$ GAE per $100 \mathrm{~mL}$ of cordial. Findings of the conducted study were in line with those reported by Cheng et al. [44] and Igual et al. [45]. They observed reduction in total phenolics contents of Citrus unshiu juice and grapefruit juice, respectively. According to de Souza et al. [46] and Rasoulian et al. [47], electromagnetic radiation generated by microwaves first liberates bound phenolics from their binding sites, then causes their cleavage due to increasing temperature, thus changing their composition and stability. In contrast to the microwave results, the storage data indicate that the total phenolic content increased considerably during storage. At 90 days, the highest mean value of $451.20 \pm 26.940 \mathrm{mg}$ GAE per $100 \mathrm{~mL}$ of cordial was recorded, whereas the lowest value of $281.00 \pm 24.474 \mathrm{mg}$ GAE per $100 \mathrm{~mL}$ of cordial was observed at 0 days. Increase in total phenolic contents of black mulberry juice was observed during storage at 3 different temperatures- -15 and $25^{\circ} \mathrm{C}$-by Jiang et al. [48]. Pandiselvam et al. [35] and Piljac-Zegarac et al. [49] explained that there is a possibility some of the peroxidase may survive the pasteurization treatment, which might promote oxidation, thus elevating the total phenolic contents. Barba et al. [50] figure out that during storage some products are formed because of Maillard reactions. These chemicals have antioxidant properties and, when combined with the Folin reagent, increase the concentration of total phenols.

Table 6. Total phenolic contents (mg GAE per $100 \mathrm{~mL}$ ) of lemon cordial.

\begin{tabular}{|c|c|c|c|c|c|}
\hline \multirow{2}{*}{ Treatments } & \multicolumn{4}{|c|}{ Storage (Days) } & \multirow{2}{*}{ Means } \\
\hline & 0 & 30 & 60 & 90 & \\
\hline $\mathrm{T}_{0-}$ & $293.00^{1} \pm 5.196$ & $368.33^{\text {gh }} \pm 2.887$ & $410.33^{\text {de }} \pm 4.619$ & $460.00^{b} \pm 5.000$ & $382.92^{\mathrm{B}} \pm 64.057$ \\
\hline $\mathrm{T}_{0+}$ & $318.33^{k} \pm 2.887$ & 369.67 gh \pm 4.041 & $413.33^{\text {de }} \pm 2.887$ & $495.00^{\mathrm{a}} \pm 5.000$ & $399.08^{\mathrm{A}} \pm 67.745$ \\
\hline $\mathrm{T}_{1}$ & $280.00^{\mathrm{m}} \pm 3.464$ & $358.33^{h i} \pm 2.887$ & $405.00^{\text {ef }} \pm 5.196$ & $448.33^{b} \pm 2.887$ & $372.92^{C} \pm 65.228$ \\
\hline $\mathrm{T}_{2}$ & $261.00^{n} \pm 3.464$ & $352.33^{i} \pm 2.887$ & $393.67^{\mathrm{f}} \pm 5.774$ & $433.33^{c} \pm 2.887$ & $360.08^{\mathrm{D}} \pm 66.904$ \\
\hline $\mathrm{T}_{3}$ & $252.67^{n} \pm 4.619$ & $336.33^{j} \pm 2.887$ & $377.33^{g} \pm 4.619$ & $419.33^{d} \pm 2.309$ & $346.42^{\mathrm{E}} \pm 64.387$ \\
\hline Means & $281.00^{\mathrm{D}} \pm 24.474$ & $357.00^{C} \pm 12.867$ & $399.93^{B} \pm 14.175$ & $451.20^{\mathrm{A}} \pm 26.940$ & \\
\hline
\end{tabular}

Values exhibiting similar small alphabets are statistically non-significant $(p>0.05)$ whereas similar capital alphabets represent statistically non-significant $(p>0.05)$ difference among overall means values. $\mathrm{T}_{0-}$-control (lemon cordial with no preservative and treatment); $\mathrm{T}_{0+}$ - control (lemon cordial preserved with KMS); $\mathrm{T}_{1}$ - microwave treatment (60 s); $\mathrm{T}_{2}$-microwave treatment (90 s); $\mathrm{T}_{3}$-microwave treatment (120 s). 
Findings regarding the influence of microwave treatment and storage on the total flavonoids content of lemon cordial at refrigerated temperature are displayed in (Table 7), which clearly depicts that the treatments and storage periods had a highly significant impact $(p \leq 0.01)$ upon total flavonoid contents. Reduction in total flavonoid contents of lemon cordial were observed upon the application of microwave treatment. The highest values of total flavonoids were exhibited by $\mathrm{T}_{0+}, 178.70 \pm 24.472 \mathrm{mg}$ CE per $100 \mathrm{~mL}$ of cordial, while the lowest values were observed in $\mathrm{T}_{3}$, exhibiting a mean value of $118.21 \pm 24.078 \mathrm{mg} \mathrm{CE}$ per $100 \mathrm{~mL}$ of cordial. Decrease in total flavonoids after microwaving was also reported by Papoutsis et al. [51], and Igual et al. [45] in Citrus limon L. pomace and grapefruit juice, respectively. They stated that higher power and long exposure time led to degradation of heat sensitive polyphenols. Cheng et al. [44] communicated that water serves as a very important medium for absorbing microwave energy. At higher temperatures and long exposure time, evaporation of water becomes rapid, thus its ability to preserve the bioactive compounds is reduced, which, ultimately, drops their concentration. Therefore, microwave power, time, frequency and temperature play very critical roles in determining the concentration of these polyphenolic constituents. Storage also caused reduction in the total flavonoid contents of lemon cordial. The highest total flavonoid contents with mean value of $174.81 \pm 23.349 \mathrm{mg}$ CE per $100 \mathrm{~mL}$ of cordial were noticed at 0 days, while the lowest contents with mean value of $117.04 \pm 21.678 \mathrm{mg} \mathrm{CE}$ per $100 \mathrm{~mL}$ of cordial was observed at 90 days. When total flavonoid contents were compared to total phenolic contents during storage, a discrepancy in the data was noticed, indicating that total flavonoid contents began to decline during storage. A 57\% reduction in total flavonoid contents was observed when comparison was carried out at beginning and at the end of storage duration. Total flavonoid contents of microwave-treated functional peach beverage and sugarcane juice also declined during storage. Sattar et al. [41] and Zia et al. [24] stated that, during storage, generation of free radicals takes place to a greater extent, which ultimately reduces the total flavonoids contents.

Table 7. Total flavonoid contents (mg CE per $100 \mathrm{~mL}$ ) of lemon cordial.

\begin{tabular}{|c|c|c|c|c|c|}
\hline \multirow{2}{*}{ Treatments } & \multicolumn{4}{|c|}{ Storage (Days) } & \multirow{2}{*}{ Means } \\
\hline & 0 & 30 & 60 & 90 & \\
\hline $\mathrm{T}_{0-}$ & $187.65^{b} \pm 5.658$ & $164.20^{\mathrm{c}-\mathrm{e}} \pm 2.14$ & $151.85^{\mathrm{e}-\mathrm{g}} \pm 3.70$ & $128.40^{j \mathrm{k}} \pm 2.138$ & $158.02^{\mathrm{B}} \pm 22.575$ \\
\hline $\mathrm{T}_{0+}$ & $209.88^{a} \pm 5.658$ & $188.89^{b} \pm 6.415$ & $167.90^{\mathrm{cd}} \pm 4.277$ & $148.15^{\mathrm{f}-\mathrm{h}} \pm 3.70$ & $178.70^{\mathrm{A}} \pm 24.472$ \\
\hline $\mathrm{T}_{1}$ & $171.60^{\mathrm{c}} \pm 4.277$ & $155.56^{\mathrm{d}-\mathrm{g}} \pm 3.7$ & $137.04^{\mathrm{h}-\mathrm{j}} \pm 3.70$ & $116.05^{\mathrm{kl}} \pm 4.277$ & $145.06^{C} \pm 21.930$ \\
\hline $\mathrm{T}_{2}$ & $158.02^{\mathrm{d}-\mathrm{f}} \pm 5.66$ & $143.21^{\mathrm{g}-\mathrm{i}} \pm 2.14$ & $124.69^{j k} \pm 2.138$ & $106.17^{1} \pm 2.138$ & $133.02^{\mathrm{D}} \pm 20.558$ \\
\hline $\mathrm{T}_{3}$ & $146.91^{\mathrm{f}-\mathrm{h}} \pm 2.14$ & $130.86^{\mathrm{ij}} \pm 4.277$ & $108.64^{1} \pm 4.277$ & $86.42^{\mathrm{m}} \pm 4.277$ & $118.21^{\mathrm{E}} \pm 24.078$ \\
\hline Means & $174.81^{\mathrm{A}} \pm 23.349$ & $156.54^{B} \pm 20.691$ & $138.02^{C} \pm 21.572$ & $117.04^{\mathrm{D}} \pm 21.678$ & \\
\hline
\end{tabular}

Values exhibiting similar small alphabets are statistically non-significant $(p>0.05)$ whereas similar capital alphabets represent statistically non-significant $(p>0.05)$ difference among overall means values. $\mathrm{T}_{0-}$-control (lemon cordial with no preservative and treatment); $\mathrm{T}_{0+}$ - control (lemon cordial preserved with KMS); $\mathrm{T}_{1}$ - microwave treatment (60 s); $\mathrm{T}_{2}$-microwave treatment $(90 \mathrm{~s}) ; \mathrm{T}_{3}$-microwave treatment (120 s).

Statistical results indicated highly significant impact $(p \leq 0.01)$ of microwave treatment, as well as storage, on the antioxidant activity of lemon cordial stored at refrigerated temperature (Table 8). Increment in total antioxidant activity of lemon cordial was observed upon the application of microwave. The highest value for total antioxidants was expressed by $\mathrm{T}_{3}$, depicting a mean value of $1212.03 \pm 716.5 \mu \mathrm{g}$ equivalent of ascorbic acid per $100 \mathrm{~mL}$ of cordial, while the lowest was observed in $\mathrm{T}_{0-}$, exhibiting a mean value of $837.73 \pm 427.1 \mu \mathrm{g}$ equivalent of ascorbic acid per $100 \mathrm{~mL}$ of cordial. Results of the conducted study coincide with the findings of Martins et al. [52] and Zia et al. [24], who proposed that total antioxidant potential of orange juicemilk beverage and sugarcane juice increased with application of microwaves, as the enzymes responsible for promoting oxidation are inhibited. Besides, microwaving also leads to greater extraction of antioxidant compounds from the product to which they are applied. Storage results revealed reduction in the total antioxidant activity of lemon cordial. The highest mean value of $1685.22 \pm 264.73 \mu \mathrm{g}$ equivalent of ascorbic 
acid per $100 \mathrm{~mL}$ of cordial for total antioxidants was noticed at 0 days, while the lowest mean value of $337.76 \pm 27.03 \mu$ g equivalent of ascorbic acid per $100 \mathrm{~mL}$ of cordial was observed at 90 days. During storage, a huge reduction in the total antioxidant activity was observed. At the end of storage, a fourfold reduction in the antioxidant activity was recorded. Results are in conformance with the findings of Jiang et al. [48], who stated that, during storage, loss in vitamin $\mathrm{C}$ and flavonoid contents triggers the reduction in the antioxidant activity of black mulberry juice. Additionally, onset of complex chemical reactions, particularly polymerization reactions, limits the availability of free hydroxyl groups, leading to diminished antioxidant potential.

Table 8. Total antioxidant activity ( $\mu$ g equivalent of ascorbic acid per $100 \mathrm{~mL}$ ) of lemon cordial.

\begin{tabular}{|c|c|c|c|c|c|}
\hline \multirow{2}{*}{ Treatments } & \multicolumn{4}{|c|}{ Storage (Days) } & \multirow{2}{*}{ Means } \\
\hline & 0 & 30 & 60 & 90 & \\
\hline $\mathrm{T}_{0-}$ & $1378.02^{\mathrm{e}} \pm 1.56$ & $1046.49^{h} \pm 0.10$ & $625.76^{\mathrm{m}} \pm 1.57$ & $300.65^{r} \pm 0.59$ & $837.73^{\mathrm{E}} \pm 427.1$ \\
\hline $\mathrm{T}_{0+}$ & $1441.08^{\mathrm{d}} \pm 2.70$ & $1120.36^{g} \pm 1.56$ & $659.10^{1} \pm 1.56$ & $317.15^{\mathrm{q}} \pm 3.25$ & $884.42^{\mathrm{D}} \pm 448.7$ \\
\hline $\mathrm{T}_{1}$ & $1683.42^{c} \pm 1.56$ & $1113.15^{\mathrm{g}} \pm 1.56$ & $685.52^{\mathrm{k}} \pm 4.99$ & $341.11^{\mathrm{P}} \pm 4.63$ & $955.80^{C} \pm 523.6$ \\
\hline $\mathrm{T}_{2}$ & $1861.80^{b} \pm 1.56$ & $1316.76^{\mathrm{f}} \pm 0.10$ & $703.24^{j} \pm 0.10$ & $359.10^{\circ} \pm 6.24$ & $1060.22^{B} \pm 601.7$ \\
\hline $\mathrm{T}_{3}$ & $2061.80^{\mathrm{a}} \pm 9.49$ & $1683.42^{\mathrm{c}} \pm 1.56$ & $732.07^{i} \pm 1.56$ & $370.81^{\mathrm{n}} \pm 0.10$ & $1212.03^{\mathrm{A}} \pm 716.5$ \\
\hline Means & $1685.22^{\mathrm{A}} \pm 264.73$ & $1256.04^{B} \pm 240.13$ & $681.14^{C} \pm 37.82$ & $337.76^{\mathrm{D}} \pm 27.03$ & \\
\hline
\end{tabular}

Values exhibiting similar small alphabets are statistically non-significant $(p>0.05)$ whereas similar capital alphabets represent statistically non-significant $(p>0.05)$ difference among overall means values. $\mathrm{T}_{0-}$ - control (lemon cordial with no preservative and treatment); $\mathrm{T}_{0+}$ - control (lemon cordial preserved with KMS); $\mathrm{T}_{1}$ - microwave treatment (60 s); $\mathrm{T}_{2}$-microwave treatment $(90 \mathrm{~s}) ; \mathrm{T}_{3}$-microwave treatment (120 s).

At refrigerated temperature, the influence of microwave and storage on the total plate count of lemon cordial is presented in (Table 9), which clearly depicts a highly significant impact $(p \leq 0.01)$. Reduction in total plate count of lemon cordial was observed, upon the application of microwave treatment. Lowest values for microbial populations were expressed by $\mathrm{T}_{0+}$ and $\mathrm{T}_{3}$, exhibiting mean values of $1.72 \pm 0.131 \mathrm{Log}{ }_{10} \mathrm{CFU} / \mathrm{mL}$ and $1.75 \pm 0.144 \log { }_{10} \mathrm{CFU} / \mathrm{mL}$ of cordial, respectively, while highest were observed in $\mathrm{T}_{0-}$, exhibiting a mean value of $1.83 \pm 0.125 \log { }_{10} \mathrm{CFU} / \mathrm{mL}$ of cordial. Observations of the conducted study correlate with investigations of Adulvitayakorn et al. [53] and Li et al. [54], who emphasized that microwaving causes cell lysis of bacteria due to coupling of electromagnetic energy. Storage results revealed an increment in the total plate count of lemon cordial. Lowest mean value of $1.58 \pm 0.052 \log { }_{10} \mathrm{CFU} / \mathrm{mL}$ of cordial for total plate count was noticed at 0 days, while highest mean value of $1.93 \pm 0.039 \log { }_{10} \mathrm{CFU} / \mathrm{mL}$ of cordial was observed at 90 days. Storage results contradict in a way that total plate count increased throughout storage. Pradhan et al. [55] claimed that, during storage of microwave-treated sugarcane juice, enhancement in total plate count was noted.

Table 9. Total plate count $\log _{10} \mathrm{CFU} / \mathrm{mL}$ of lemon cordial.

\begin{tabular}{|c|c|c|c|c|c|}
\hline \multirow{2}{*}{ Treatments } & \multicolumn{4}{|c|}{ Storage (Days) } & \multirow{2}{*}{ Means } \\
\hline & 0 & 30 & 60 & 90 & \\
\hline $\mathrm{T}_{0-}$ & $1.65^{\mathrm{ij}} \pm 0.023$ & $1.80^{\mathrm{f}} \pm 0.017$ & $1.89^{\mathrm{b}-\mathrm{d}} \pm 0.012$ & $1.97^{\mathrm{a}} \pm 0.012$ & $1.83^{\mathrm{A}} \pm 0.125$ \\
\hline $\mathrm{T}_{0+}$ & $1.53^{\mathrm{m}} \pm 0.029$ & $1.71^{\mathrm{hi}} \pm 0.023$ & $1.78^{\mathrm{fg}} \pm 0.006$ & $1.86^{\mathrm{de}} \pm 0.006$ & $1.72^{\mathrm{D}} \pm 0.131$ \\
\hline $\mathrm{T}_{1}$ & $1.61^{\mathrm{jk}} \pm 0.023$ & $1.79^{\mathrm{f}} \pm 0.017$ & $1.89^{\mathrm{cd}} \pm 0.012$ & $1.95^{\mathrm{ab}} \pm 0.012$ & $1.81^{\mathrm{B}} \pm 0.132$ \\
\hline $\mathrm{T}_{2}$ & $1.59^{\mathrm{kl}} \pm 0.023$ & $1.77^{\mathrm{fg}} \pm 0.017$ & $1.87^{\text {de }} \pm 0.012$ & $1.93^{\mathrm{a}-\mathrm{c}} \pm 0.012$ & $1.79^{\mathrm{B}} \pm 0.137$ \\
\hline $\mathrm{T}_{3}$ & $1.54^{\mathrm{lm}} \pm 0.029$ & $1.73^{\mathrm{gh}} \pm 0.017$ & $1.82^{\text {ef }} \pm 0.012$ & $1.91^{\mathrm{b}-\mathrm{d}} \pm 0.012$ & $1.75^{\mathrm{C}} \pm 0.144$ \\
\hline Means & $1.58^{\mathrm{D}} \pm 0.052$ & $1.76^{\mathrm{C}} \pm 0.040$ & $1.85^{\mathrm{B}} \pm 0.044$ & $1.93^{\mathrm{A}} \pm 0.039$ & \\
\hline
\end{tabular}

Values exhibiting similar small alphabets are statistically non-significant $(p>0.05)$ whereas similar capital alphabets represent statistically non-significant $(p>0.05)$ difference among overall means values. $\mathrm{T}_{0-}$-control (lemon cordial with no preservative and treatment); $\mathrm{T}_{0+}$ - control (lemon cordial preserved with KMS); $\mathrm{T}_{1}$ - microwave treatment (60 s); $\mathrm{T}_{2}$-microwave treatment (90 s); $\mathrm{T}_{3}$-microwave treatment (120 s). 


\section{Conclusions}

It was observed that microwaving resulted in a nutritious and shelf-stable product, as it exhibited great antioxidant potential and low microbial counts in formulated lemon cordial. Furthermore, microwave treatment also enhanced the physicochemical profile of the constituted lemon cordial; however, at greater exposure time, there was a reduction in phytochemical constituents. Treatment $\mathrm{T}_{3}$, microwaved for $120 \mathrm{~s}$, showed better results in terms of physicochemical attributes, antioxidant capacity and microbial counts. It is thus suggested that microwaving should be used at both laboratory and industrial scales as an alternative to chemical preservatives and thermal methods, owing to its cost effectiveness and ease in processing. Additionally, it produces minimally processed products with great shelf stability and high nutritional value.

Author Contributions: Conceptualization, F.M.; data curation, F.M. and A.I.; formal analysis, F.M. and A.I.; funding acquisition, S.F.M., G.A.A., H.A.A.-J. and E.H.A.A.; investigation, F.M. and A.I.; methodology, F.M. and A.A.; resources, M.N. and A.A.; software, M.N. and A.A.; validation, M.N., A.A. and R.K.; visualization, M.N., A.A., R.K., M.S., S.F.M., G.A.A., H.A.A.-J. and E.H.A.A.; writingoriginal draft preparation, F.M. and A.I.; writing-review and editing, M.N., A.A., R.K., M.S., S.F.M., G.A.A., H.A.A.-J. and E.H.A.A. All authors have read and agreed to the published version of the manuscript.

Funding: The authors would like to acknowledge the financial support of Taif University Researchers Supporting Project number (TURSP-2020/138), Taif University, Taif, Saudi Arabia.

Institutional Review Board Statement: Not applicable.

Informed Consent Statement: Not applicable.

Data Availability Statement: Data are contained within the article.

Acknowledgments: The authors would like to acknowledge the financial support of Taif University Researchers Supporting Project number (TURSP-2020/138), Taif University, Taif, Saudi Arabia.

Conflicts of Interest: The authors declare no conflict of interest.

\section{References}

1. Jabbar, S.; Abid, M.; Hu, B.; Wu, T.; Hashim, M.M.; Lei, S.; Zhu, X.; Zeng, X. Quality of Carrot Juice as Influenced by Blanching and Sonication Treatments. LWT-Food Sci. Technol. 2014, 55, 16-21. [CrossRef]

2. Miller, H.E.; Rigelhof, F.; Marquart, L.; Prakash, A.; Kanter, M. Antioxidant Content of Whole Grain Breakfast Cereals, Fruits and Vegetables. J. Am. Coll. Nutr. 2000, 19, 312S-319S. [CrossRef]

3. Pomerleau, J.; Lock, K.; McKee, M. The Burden of Cardiovascular Disease and Cancer Attributable to Low Fruit and Vegetable Intake in the European Union: Differences between Old and New Member States. Public Health Nutr. 2006, 9, 575-583. [CrossRef] [PubMed]

4. $\quad$ Broekmans, W.M.R.; Klö Pping-Ketelaars, I.A.A.; Schuurman, C.R.W.C.; Verhagen, H.; van den Berg, H.; Kok, F.J.; van Poppel, G. Fruits and Vegetables Increase Plasma Carotenoids and Vitamins and Decrease Homocysteine in Humans. J. Nutr. 2000, 1, 1578-1583. [CrossRef] [PubMed]

5. Lücker, J.; el Tamer, M.K.; Schwab, W.; Verstappen, F.W.A.; van der Plas, L.H.W.; Bouwmeester, H.J.; Verhoeven, H.A. Monoterpene Biosynthesis in Lemon (Citrus Limon) CDNA Isolation and Functional Analysis of Four Monoterpene Synthases. Eur. J. Biochem. 2002, 269, 3160-3171. [CrossRef]

6. Sarker, N.I.; Barman, S.C.; Islam, M.; Chakma, A.S. Role of Lemon (Citrus Limon) Production on Livelihoods of Rural People in Bangladesh. J. Agric. Econ. Rural. Dev. 2017, 3, 167-175.

7. Xi, W.; Lu, J.; Qun, J.; Jiao, B. Characterization of Phenolic Profile and Antioxidant Capacity of Different Fruit Part from Lemon (Citrus Limon Burm.) Cultivars. J. Food Sci. Technol. 2017, 54, 1108-1118. [CrossRef]

8. Del Río, J.A.; Fuster, M.D.; Gómez, P.; Porras, I.; García-Lidón, A.; Ortuño, A. Citrus Limon: A Source of Flavonoids of Pharmaceutical Interest. Food Chem. 2004, 84, 457-461. [CrossRef]

9. Saleem, F.; Sarkar, D.; Ankolekar, C.; Shetty, K. Phenolic Bioactives and Associated Antioxidant and Anti-Hyperglycemic Functions of Select Species of Apiaceae Family Targeting for Type 2 Diabetes Relevant Nutraceuticals. Ind. Crops Prod. 2017, 107, 518-525. [CrossRef]

10. Mabberley, D.J. Citrus (Rutaceae): A Review of Recent Advances in Etymology, Systematics and Medical Applications. Blumea J. Plant Taxon. Plant Geogr. 2004, 49, 481-498. [CrossRef] 
11. Cañumir, J.A.; Celis, J.E.; de Bruijn, J.; Vidal, L.V. Pasteurisation of Apple Juice by Using Microwaves. LWT-Food Sci. Technol. 2002, 35, 389-392. [CrossRef]

12. Yusof, S.; Kok Chiong, L. Effects of Brix, Processing Techniques and Storage Temperature on the Quality of Carambola Fruit Cordial. Food Chem. 1997, 59, 27-32. [CrossRef]

13. Siddique, M.I.; Gamevska, E. Citrus value chain (s): A survey of Pakistan citrus industry. Agric. Value Chain 2018, 37-53. [CrossRef]

14. Fazaeli, M.; Yousefi, S.; Emam-Djomeh, Z. Investigation on the Effects of Microwave and Conventional Heating Methods on the Phytochemicals of Pomegranate (Punica Granatum L.) and Black Mulberry Juices. Food Res. Int. 2013, 50, 568-573. [CrossRef]

15. Shams Najafabadi, N.; Sahari, M.A.; Barzegar, M.; Hamidi Esfahani, Z. Effects of Concentration Method and Storage Time on Some Bioactive Compounds and Color of Jujube (Ziziphus Jujuba Var Vulgaris) Concentrate. J. Food Sci. Technol. 2017, 54, 2947-2955. [CrossRef]

16. Renge, M.M.; Suryawanshi, H.M. Five-Level Diode Clamped Inverter to Eliminate Common Mode Voltage and Reduce Dv/Dt in Medium Voltage Rating Induction Motor Drives. IEEE Trans. Power Electron. 2008, 23, 1598-1607. [CrossRef]

17. Maskan, M. Production of Pomegranate (Punica Granatum L.) Juice Concentrate by Various Heating Methods: Colour Degradation and Kinetics. J. Food Eng. 2006, 72, 218-224. [CrossRef]

18. Anand, S.; Sati, N. Artificial Preservatives and Their Harmful Effects: Looking Toward Nature for Safer Alternatives. Int. J. Pharm. Sci. Res. 2013, 4, 2496. [CrossRef]

19. Carocho, M.; Barreiro, M.F.; Morales, P.; Ferreira, I.C.F.R. Adding Molecules to Food, Pros and Cons-A Review on Synthetic and Natural Food Additives. Compr. Rev. Food Sci. Food Saf. 2014, 13, 377-399. [CrossRef] [PubMed]

20. Anyasi, T.A.; Jideani, A.I.O.; Mchau, G.R.A. Effects of Organic Acid Pretreatment on Microstructure, Functional and Thermal Properties of Unripe Banana Flour. J. Food Meas. Charact. 2017, 11, 99-110. [CrossRef]

21. Fundo, J.F.; Miller, F.A.; Tremarin, A.; Garcia, E.; Brandão, T.R.S.; Silva, C.L.M. Quality Assessment of Cantaloupe Melon Juice under Ozone Processing. Innov. Food Sci. Emerg. Technol. 2018, 47, 461-466. [CrossRef]

22. Shah Sulaiman, N.N.A.K.; Sidek, A.; Supian, N.S.M. Quality Assessment of Ozone-Treated Citrus Fruit Juices. Int. Food Res. J. 2019, 26, 1405-1415.

23. Benlloch-Tinoco, M.; Igual, M.; Rodrigo, D.; Martínez-Navarrete, N. Superiority of Microwaves over Conventional Heating to Preserve Shelf-Life and Quality of Kiwifruit Puree. Food Control. 2015, 50, 620-629. [CrossRef]

24. Zia, S.; Khan, M.R.; Zeng, X.A.; Sehrish Shabbir, M.A.; Aadil, R.M. Combined Effect of Microwave and Ultrasonication Treatments on the Quality and Stability of Sugarcane Juice during Cold Storage. Int. J. Food Sci. Technol. 2019, 54, 2563-2569. [CrossRef]

25. Math, R.G.; Nayani, S. Continuous Microwave Processing and Preservation of Acidic and Non Acidic Juice Blends. IJAFST Int. J. Agric. Food Sci. Technol. 2014, 5, 81-90.

26. Stratakos, A.C.; Delgado-Pando, G.; Linton, M.; Patterson, M.F.; Koidis, A. Industrial Scale Microwave Processing of Tomato Juice Using a Novel Continuous Microwave System. Food Chem. 2016, 190, 622-628. [CrossRef] [PubMed]

27. Helali, M.O.H.; Ibrahim, M.; Shafique, M.Z.; Rahman, M.M.; Biswas, S.K.; Islam, M.S. Formulation, preparation and preservation of lemon (Citrus Limon 1.) cordial. J. Bio-Sci. 2008, 16, 125-127. [CrossRef]

28. AOAC. Official Methods of Analysis, 18th ed.; The Association of Official Analytical Chemists: Gaithersburg, MD, USA, 2011.

29. Saeeduddin, M.; Abid, M.; Jabbar, S.; Hu, B.; Hashim, M.M.; Khan, M.A.; Xie, M.; Wu, T.; Zeng, X. Physicochemical Parameters, Bioactive Compounds and Microbial Quality of Sonicated Pear Juice. Int. J. Food Sci. Technol. 2016, 51, 1552-1559. [CrossRef]

30. Abid, M.; Jabbar, S.; Hu, B.; Hashim, M.M.; Wu, T.; Wu, Z.; Khan, M.A.; Zeng, X. Synergistic Impact of Sonication and High Hydrostatic Pressure on Microbial and Enzymatic Inactivation of Apple Juice. LWT-Food Sci. Technol. 2014, 59, 70-76. [CrossRef]

31. Prieto, P.; Pineda, M.; Aguilar, M. Spectrophotometric Quantitation of Antioxidant Capacity through the Formation of a Phosphomolybdenum Complex: Specific Application to the Determination of Vitamin E. Anal. Biochem. 1999, $269,337-341$. [CrossRef]

32. FDA. U.S. Food and Drug Administration Bacteriological Analytical Manual, 8th ed.; FDA Center for Food Safety and Applied Nutrition: Silver Spring, MD, USA, 2001.

33. Maturin, L.; Peeler, J.T. BAM: Aerobic Plate Count; US Food and Drug Administration: Silver Spring, MD, USA, 2001.

34. Steel, R.G.D.; Torrie, J.H.; Dicky, D.A. Principles and Procedures of Statistics: A Biometrical Approaches, 3rd ed.; McGraw Hill Book Co., Inc.: Singapore, 1997; pp. 204-227.

35. Pandiselvam, R.; Hebbar, K.B.; Manikantan, M.R.; Prashanth, B.K.; Beegum, S.; Ramesh, S.V. Microwave Treatment of Coconut Inflorescence Sap (Kalparasa ${ }^{\circledR}$ ): A Panacea to Preserve Quality Attributes. Sugar Tech 2020, 22, 718-726. [CrossRef]

36. Bozkir, H.; Baysal, T. Concentration of Apple Juice Using a Vacuum Microwave Evaporator as a Novel Technique: Determination of Quality Characteristics. J. Food Process Eng. 2017, 40, e12535. [CrossRef]

37. Thirukkumar, S.; Vennila, P.; Kanchana, S. Physico-Chemical Characteristics of Noni Fruit Juice Blended Squashes during Storage. Int. J. Chem. Stud. 2018, 6, 449-455.

38. Jothi, J.S.; Karmoker, P.; Sarower, K. Quality Assessment of Mixed Fruit Squash: Physico-Chemical Analysis, Sensory Evaluation and Storage Studies. J. Bangladesh Agric. Univ. 2014, 12, 195-201. [CrossRef]

39. Picouet, P.A.; Landl, A.; Abadias, M.; Castellari, M.; Viñas, I. Minimal Processing of a Granny Smith Apple Purée by Microwave Heating. Innov. Food Sci. Emerg. Technol. 2009, 10, 545-550. [CrossRef] 
40. Yadav, S.R.; Gehlot, S.; Siddiqui, G.R.B. Changes in chemical constituents and overall acceptability of guavamango ready-to-serve (RTS) drink and squash. Beverage Food World 2014, 41, 30-33.

41. Sattar, S.; Ahmad, T.; Mahr-un, N.; Imran, M.; Holmes, M.; Maycock, J.; Nadeem, M.; Khan, M.K. Microwave Processing Impact on Physicochemical and Bioactive Attributes of Optimized Peach Functional Beverage. J. Food Process. Preserv. 2019,43, e13952. [CrossRef]

42. Song, W.J.; Sung, H.J.; Kang, D.H. Inactivation of Escherichia Coli O157: H7 and Salmonella Typhimurium in Apple Juices with Different Soluble Solids Content by Combining Ozone Treatment with Mild Heat. J. Appl. Microbiol. 2015, 118, 112-122. [CrossRef]

43. Fazaeli, M.; Hojjatpanah, G.; Emam-Djomeh, Z. Effects of Heating Method and Conditions on the Evaporation Rate and Quality Attributes of Black Mulberry (Morus Nigra) Juice Concentrate. J. Food Sci. Technol. 2013, 50, 35-43. [CrossRef]

44. Cheng, C.-X.; Jia, M.; Gui, Y.; Ma, Y. Comparison of the Effects of Novel Processing Technologies and Conventional Thermal Pasteurisation on the Nutritional Quality and Aroma of Mandarin (Citrus Unshiu) Juice. Innov. Food Sci. Emerg. Technol. 2020, 64, 102425. [CrossRef]

45. Igual, M.; García-Martínez, E.; Camacho, M.M.; Martínez-Navarrete, N. Effect of Thermal Treatment and Storage on the Stability of Organic Acids and the Functional Value of Grapefruit Juice. Food Chem. 2010, 118, 291-299. [CrossRef]

46. De Souza Comapa, S.; Carvalho, L.M.S.; Lamarão, C.V.; das Chagas do Amaral Souza, F.; Aguiar, J.P.L.; da Silva, L.S.; Mar, J.M.; Sanches, E.A.; dos Santos, F.F.; de Araújo Bezerra, J.; et al. Microwave Processing of Camu-Camu Juices: Physicochemical and Microbiological Parameters. J. Food Process. Preserv. 2019, 43, e13989. [CrossRef]

47. Rasoulian, S.S.; Aminifar, M.; Rashidi, L. Investigating the effect of two different thermal methods of rotary evaporation and microwave on the phenolic content, antioxidant activity and color of grapefruit juice concentrate. Iran. J. Nutr. Sci. Food Technol. 2017, 12, 47-54.

48. Jiang, B.; Mantri, N.; Hu, Y.; Lu, J.; Jiang, W.; Lu, H. Evaluation of Bioactive Compounds of Black Mulberry Juice after Thermal, Microwave, Ultrasonic Processing, and Storage at Different Temperatures. Food Sci. Technol. Int. 2015, 21, 392-399. [CrossRef]

49. Piljac-Žegarac, J.; Valek, L.; Martinez, S.; Belščak, A. Fluctuations in the Phenolic Content and Antioxidant Capacity of Dark Fruit Juices in Refrigerated Storage. Food Chem. 2009, 113, 394-400. [CrossRef]

50. Barba, F.J.; Esteve, M.J.; Frígola, A. High Pressure Treatment Effect on Physicochemical and Nutritional Properties of Fluid Foods During Storage: A Review. Compr. Rev. Food Sci. Food Saf. 2012, 11, 307-322. [CrossRef]

51. Papoutsis, K.; Pristijono, P.; Golding, J.B.; Stathopoulos, C.E.; Bowyer, M.C.; Scarlett, C.J.; Vuong, Q.V. Enhancement of the total phenolic compounds andantioxidant activity of aqueous Citrus Limon L. pomace extract using microwavepretreatment on the dry powder. J. Food Process. Preserv. 2017, 41, e13152. [CrossRef]

52. Martins, C.C.P.; Cavalcanti, R.N.; Cardozo, F.T.S.; Couto, S.M.; Esmerino, A.; Guimarães, J.T.; Balthazar, C.F.; Rocha, R.S.; Pimentel, T.C.; Freitas, M.Q.; et al. Effects of Microwave Heating on the Chemical Composition and Bioactivity of Orange Juice-Milk Beverages. Food Chem. 2021, 345, 128746. [CrossRef] [PubMed]

53. Adulvitayakorn, S.; Azhari, S.H.; Hasan, H. The Effects of Conventional Thermal, Microwave Heating, and Thermosonication Treatments on the Quality of Sugarcane Juice. J. Food Process. Preserv. 2020, 44, e14322. [CrossRef]

54. Li, T.; Li, J.; Hu, W.; Zhang, X.; Li, X.; Zhao, J. Shelf-Life Extension of Crucian Carp (Carassius Auratus) Using Natural Preservatives during Chilled Storage. Food Chem. 2012, 135, 140-145. [CrossRef]

55. Pradhan, N.; Kumar, D.; Singh, P.; Pisalkar, P.S. Sensory and Microbial Evaluation of Microwave Treated Sugarcane Juice. Int. J. Curr. Microbiol. Appl. Sci. 2020, 9, 1313-1320. [CrossRef] 